Bangladesh J. Plant Taxon. 23(2): 223-235, 2016 (December)

(C) 2016 Bangladesh Association of Plant Taxonomists

\title{
MOLECULAR SYSTEMATICS OF SOME BIFURCATE HAIRY SECTIONS IN ASTRAGALUS L. (FABACEAE) AS INFERRED FROM NUCLEAR AND CHLOROPLAST DNA SEQUENCES
}

\author{
Reza SHeiKhaKbari-Mehr ${ }^{1}$, Ali Asghar MaAssoumi ${ }^{2}$ and \\ SHAHROKH KaZEMPOUR OSALOO ${ }^{3}$ \\ Department of Biology, Faculty of Science, University of Qom, Qom, Iran \\ Keywords: Astragalus; cpDNA; Fabaceae; nrDNA ITS; Phylogeny.
}

\begin{abstract}
In this study, 38 species belonging to some bifurcate hairy sections of Astragalus L. were analyzed phylogenetically, using nuclear and plastid DNA sequences. Based on our results, Astragalus sect. Dissitiflori DC. with the inclusion of the members of section Erioceras Bunge, formed a monophyletic group. The members of sect. Ornithopodium Bunge and Onobrychoidei DC. were located together within a highly supported monophyletic clade, apart from other sections studied, on the basis of the present molecular data.The positioning of the enigmatic, recently established species, A. juladakensis Maassoumi, within the sect. Dissitiflori was verified. In addition, our results showed that $A$. pravitzii Podl., which had been already transferred to sect. Ornithopodium, belongs to the section Dissitiflori.
\end{abstract}

\section{Introduction}

Astragalus L. (family Fabaceae, subfamily Faboideae) is among the largest genera of the flowering plants containing up to 3000 species of herbs and small shrubs (Maassoumi, 2005; Lewis et al., 2005).The south-western and central Asia are considered as the main centers of biodiversity for the Old World Astragalus (Lock and Simpson, 1991). Infrageneric and sectional classification of Astragalus was first carried out by De Candolle (1825) with the description of 14 sections, a number then increased by Boissier (1843).However, the first comprehensive classification of the Old World Astragalus was presented by Bunge (1868), with the description of 150 sections in 10 subgenera. The current distinction of 150 and 93 sections belonging to the Old World and New World Astragalus respectively indicates that Astragalus is a complex genus within Angiosperms (Barneby, 1964; Podlech, 1986). These sections are distinguished based on some morphological characters such as stem features, stipules connation, leaf shape, inflorescence and legume features (Maassoumi, 2000). There are more than 800 species of Astragalus in Iran, which has a high endemism rate of 65\% (Podlech, 1999; Maassoumi, 2005).

Astragalus sect. Dissitiflori DC is one of the largest sections among bifurcate hairy Astragalus, with more than 150 species in the world (Ranjbar, 2004) and about 20 species in Iran (Podlech et al., 2010). Ghahreman et al., (1996) transferred A. viridis Bunge and A. dendroproselius Rech. f. from Dissitiflori to the section Cystodes Bunge. Later on, these two species along with A. aestimabilis Podlech were moved to sect. Corethrum Bunge (Maassoumi, 2005). According to Maassoumi (2005), sect. Corethrum Bunge is closely related to sect. Dissitiflori but differs from that especially in having oblong elliptic pods and long spreading hairs

\footnotetext{
${ }^{1}$ Corresponding author. Email: r.sheikhakbari@qom.ac.ir; reza.sheikhakbari@gmail.com

${ }^{2}$ Botany Division, Research Institute of Forests and Rangelands, Tehran, Iran.

${ }^{3}$ Department of Botany, Faculty of Biological Sciences, Tarbiat Modares University, Tehran, Iran.
} 
on fruit. Therefore, this section was recorded for Iran by transferring three aforementioned species from sect. Dissitiflori based on their fruit characteristics (Maassoumi, 2005).

Astragalus sect. Erioceras Bunge is closely related to the Dissitiflori and has been probably evolved by shortening of stem in the latter (Ranjbar and Karamian, 2002). The species of sect. Erioceras are xerophytes and more or less caespitose in contrast to many other bifurcate hairy sections.

Sect. Cytisodes Bunge which was originally established by Bunge (1868) with one species is now presented by 17 species (Podlech, 2010). This section was included in Flora of Iran after discovery of a new species, A. gigantirostratus Maassoumi et al., (1999). Later on, Podlech (2004) published another new species belonging to sect. Cytisodes in Iran. Recently Maassoumi (2005) transferred A. zoshkensis Ghahremani, from section Dissitiflori to the Cytisodes. However, according to the latest revision of Astragalus in Flora Iranica, section Cytisodes has only two species in Iran (Podlech et al., 2010).

The only inclusive molecular phylogenetic analyses of the Old World Astragalus, using nrDNA ITS and in part plastid gene $n d h F$ sequences are those of Kazempour Osaloo et al., (2003, 2005). Based on these studies, large sections of Astragalus such as Incani DC., Cenanthrum Bunge and Ammodendron Bunge formed monophyletic groups. In contrast, sections Chlorostachys Bunge, Hystrix Bunge, Heterodonthus Bunge, Hymenostegis Bunge, Acidodes Bunge, Rhacophorus Bunge and Iranian endemic section Leucocercis Bunge are not monophyletic. Moreover, monophyly of sections Dissitiflori DC., Erioceras Bunge, Laguropsis Bunge, Macrocystis Popov, Stenonychium Bunge, and Onobrychoidei DC. remained unresolved (Kazempour Osaloo et al., 2005).

The aims of this study were: 1) to evaluate the phylogenetic status of sections Dissitiflori and Erioceras in Iran, on the basis of nrDNA and cpDNA sequences, and 2) to find the correct position of some problematic species i.e. A. juladakensis Maassoumi (2007), A. pravitzii Podlech (2001), and A. zoshkensis Ghahremani-nejad (2003)) related to these sections.

\section{Materials and Methods}

Taxon sampling

A total of 38 taxa were chosen as in-group for nrDNA ITS, and cpDNA trnH-psbA, matK (as partial), and trnT-trnY sequence analyses (Table 1). The in-group mainly belonged to sections Dissitiflori and Erioceras. In order to determine the situation of some controversial species, a number of representatives pertaining to the closely related sections such as Ornithopodium Bunge, Onobrychoidei, and Cytisodes were introduced in the analyses. Astragalus stocksii Bunge and A. frigidus (L.) A. Gray was chosen as outgroups following previous molecular phylogenetic studies in the Old World Astragalus (Kazempour Osaloo et al., 2003, 2005; Sheikh Akbari-Mehr et al., 2012a, 2012b). The cpDNA sequences for majority of in-group and ITS for 16 species (marked with an asterisk at Table 1) are published here for the first time.

\section{DNA extraction, PCR and Sequencing}

Total genomic DNA was extracted from dry leaves of individual plants, deposited in Central Herbarium of Iran (TARI) and Ferdowsi University of Mashhad Herbarium (FUMH), following the modified CTAB procedure of Doyle and Doyle (1987). The complete nrDNAITS+5.8S region was amplified using primers ITS4 of White et al., (1990) and ITS5m of Sang et al., (1997). The cpDNA matK (partial), trnH-psbA and trnT-trnY regions were amplified using primers trnK-F and matK-R (Wojciechowski et al., 2004), trnH and psbA (Tate and Simpson, 2003) and trnT and 
Table 1. Taxa included in the molecular analyses and their voucher specimens. Sequences obtained from GenBank marked with an asterisk.

\begin{tabular}{|c|c|c|c|c|c|}
\hline \multirow[t]{2}{*}{ Species } & \multirow[t]{2}{*}{ Voucher no. } & \multicolumn{4}{|c|}{ GenBank accession no. } \\
\hline & & ITS & $\operatorname{trnT} / \mathrm{Y}$ & $\operatorname{trnH} / p s b \mathrm{~A}$ & matK \\
\hline $\begin{array}{l}\text { Astragalus argyroides } \\
\text { Beck. }\end{array}$ & $\begin{array}{l}\text { Mozaffarian \& Freitag, } \\
\text { 28538(TARI) }\end{array}$ & *AB721936 & LC129368 & LC129321 & *AB727543 \\
\hline A. aucheri Boiss. & Mottaghi, 1061(TARI) & *AB721937 & - & LC129319 & - \\
\hline $\begin{array}{l}\text { A. argentocalyx Ali ex } \\
\text { Podl. }\end{array}$ & $\begin{array}{l}\text { Ghahremaninejad \& } \\
\text { Joharchi, 34738(TARI) }\end{array}$ & LC129287 & - & LC129323 & LC129310 \\
\hline $\begin{array}{l}\text { A. eburneusBorn. \& } \\
\text { Gauba }\end{array}$ & $\begin{array}{l}\text { Mozaffarian, } \\
\text { 44936(TARI) }\end{array}$ & *AB721938 & LC129353 & LC129318 & LC129299 \\
\hline $\begin{array}{l}\text { A. husseinovii } \\
\text { Rezazade }\end{array}$ & $\begin{array}{l}\text { Maassoumi \& Safavi, } \\
\text { 8721(TARI) }\end{array}$ & *AB721939 & - & LC129341 & LC129308 \\
\hline $\begin{array}{l}\text { A. juratzkanus Freyn \& } \\
\text { Sint. }\end{array}$ & $\begin{array}{l}\text { Maassoumi \& Pakravan, } \\
\text { 72351(TARI) }\end{array}$ & *AB721940 & LC129366 & LC129347 & LC129306 \\
\hline $\begin{array}{l}\text { A. melanocalyx Boiss. } \\
\text { \& Buhse }\end{array}$ & $\begin{array}{l}\text { Noruzi \& Feizi, } \\
\text { 5860(TARI) }\end{array}$ & *AB721941 & LC129357 & LC129335 & LC129298 \\
\hline $\begin{array}{l}\text { A. baraftabensis } \\
\text { Maass.\& Podl. }\end{array}$ & Tayebi, 4458(TARI) & *AB721942 & LC129352 & LC129317 & LC129307 \\
\hline $\begin{array}{l}\text { A. nigrolineatus Sirj. \& } \\
\text { Rech.f. }\end{array}$ & $\begin{array}{l}\text { Faghihnia \& } \\
\text { Zangooee,29042(FMUH) }\end{array}$ & *AB721943 & LC129367 & LC129324 & LC129297 \\
\hline A. pravitzii Podl. & Foroughi,2183(TARI) & *AB721944 & LC129358 & LC129332 & *AB727544 \\
\hline A. ruscifolius Boiss. & $\begin{array}{l}\text { Mozaffarian \& Freitag, } \\
\text { 28640(TARI) }\end{array}$ & *AB721945 & LC129369 & LC129320 & *AB727545 \\
\hline A. sitiens Bge. & $\begin{array}{l}\text { Wendelbo \& Foroughi, } \\
\text { 11270(TARI) }\end{array}$ & *AB721947 & LC129362 & LC129333 & LC129305 \\
\hline $\begin{array}{l}\text { A. saadatabadensis } \\
\text { Podl. }\end{array}$ & Grant, 15784(TARI) & *AB721946 & - & LC129330 & LC129292 \\
\hline A. sumbari Popov & $\begin{array}{l}\text { Wendelbo \& Foroughi, } \\
\text { 11063(TARI) }\end{array}$ & *AB721948 & LC129370 & LC129316 & - \\
\hline A. xiphidium Bge. & Youssefi, 7611(TARI) & *AB721949 & - & LC129336 & LC129296 \\
\hline $\begin{array}{l}\text { A. juladakensis } \\
\text { Maassoumi }\end{array}$ & $\begin{array}{l}\text { Maassoumi, } 39383 \\
\text { (TARI) }\end{array}$ & *AB721950 & - & LC129340 & LC129295 \\
\hline A. aestimabilis Podl. & Dehshiri, 38523(TARI) & *AB721951 & - & - & - \\
\hline $\begin{array}{l}\text { A. dendroproselius } \\
\text { Rech.f. }\end{array}$ & Dehshiri, 30231(TARI) & *AB721952 & - & LC129322 & LC129293 \\
\hline A. viridis Bunge. & Moussavi, 1152(TARI) & *AB721953 & - & LC129345 & - \\
\hline $\begin{array}{l}\text { A. zoshkensis F. } \\
\text { Ghahremani }\end{array}$ & $\begin{array}{l}\text { Mozaffarian, } \\
\text { 77059(TARI) }\end{array}$ & *AB721954 & LC129360 & LC129331 & LC129294 \\
\hline $\begin{array}{l}\text { A. gigantirostratus } \\
\text { Maassoumi et al., }\end{array}$ & $\begin{array}{l}\text { Maassoumi \& al., } \\
\text { 72339(TARI) }\end{array}$ & *AB721955 & - & LC129338 & - \\
\hline A. anacamptus Bunge. & $\begin{array}{l}\text { Emadzadeh \& al., } \\
\text { 35908(FUMH) }\end{array}$ & * AB721956 & LC129365 & LC129327 & LC129311 \\
\hline $\begin{array}{l}\text { A. djenarensis Sirj. \& } \\
\text { Rech.f. }\end{array}$ & $\begin{array}{l}\text { Joharchi \& Zangooee, } \\
\text { 1100(TARI) }\end{array}$ & *AB721957 & LC129355 & LC129342 & LC129303 \\
\hline A. stocksii Bunge. & Foroughi, 10802(TARI) & *AB051966 & *AB741437 & - & *AB741345 \\
\hline $\begin{array}{l}\text { A. frigidus(L.) A. } \\
\text { Gray }\end{array}$ & 5732(TARI) & *AM943381 & *AB741412 & - & *AB741320 \\
\hline
\end{tabular}


Table 1 contd.

\begin{tabular}{|c|c|c|c|c|c|}
\hline \multirow[t]{2}{*}{ Species } & \multirow[t]{2}{*}{ Voucher no. } & \multicolumn{4}{|c|}{ GenBank accession no. } \\
\hline & & ITS & $\operatorname{trn} \mathrm{T} / \mathrm{Y}$ & $\operatorname{trnH} / p s b \mathrm{~A}$ & matK \\
\hline $\begin{array}{l}\text { A. bifoliolatus Sirj. \& } \\
\text { Rech.f. }\end{array}$ & $\begin{array}{l}\text { Asadi \& Amirabadi, } \\
\text { 9342(TARI) }\end{array}$ & LC129283 & LC129361 & - & LC129309 \\
\hline A. alamliensis Rech.f. & Asadi, 84461(TARI) & LC129284 & - & LC129334 & - \\
\hline A. catacamptus Bunge & $\begin{array}{l}\text { Dini \& bazargan, } \\
\text { 5328(TARI) }\end{array}$ & LC129288 & - & LC129329 & LC129312 \\
\hline A. keredjensis Podl. & Asadi, 82404(TARI) & LC129291 & LC129355 & LC129328 & - \\
\hline A. neosytinii Ranjbar & Asadi, 84571(TARI) & LC129280 & LC129354 & LC129343 & LC129301 \\
\hline A. nubicola Podl. & Wendelbo, 11165(TARI) & LC129289 & - & LC129339 & - \\
\hline $\begin{array}{l}\text { A. pakravaniae Podlech } \\
\text { \& Maassoumi }\end{array}$ & $\begin{array}{l}\text { Asadi \& Maassoumi, } \\
\text { 55534(TARI) }\end{array}$ & LC129286 & - & LC129337 & - \\
\hline A. pentanthus Boiss. & Maroofi, 1917(TARI) & LC129290 & LC129363 & LC129325 & LC129302 \\
\hline $\begin{array}{l}\text { A. sympiliecarpus } \\
\text { Rech.f. }\end{array}$ & $\begin{array}{l}\text { Asadi \& Maassoumi, } \\
\text { 83362(TARI) }\end{array}$ & LC129285 & LC129351 & LC129344 & LC129300 \\
\hline $\begin{array}{l}\text { A. versipilus Rech.f. } \\
\text { \& Koie }\end{array}$ & $\begin{array}{l}\text { Asadi \& Amirabadi, } \\
\text { 84615(TARI) }\end{array}$ & LC129281 & LC129356 & LC129346 & LC129313 \\
\hline $\begin{array}{l}\text { A. brachyodontus } \\
\text { Boiss. }\end{array}$ & $\begin{array}{l}\text { Asadi \& Wendelbo, } \\
\text { 27666(TARI) }\end{array}$ & *AB727530 & - & - & *AB727537 \\
\hline $\begin{array}{l}\text { A. jodostachys Boiss. } \\
\& \text { Buhse }\end{array}$ & $\begin{array}{l}\text { Abuhamzeh \& } \\
\text { Maassoumi, } \\
\text { 45496(TARI) }\end{array}$ & *AB727532 & - & - & *AB727539 \\
\hline $\begin{array}{l}\text { A. gotkschaicus } \\
\text { Grossh. }\end{array}$ & $\begin{array}{l}\text { Asadi \& Foroughi, } \\
\text { 13756(TARI) }\end{array}$ & *AB727515 & LC129372 & LC129350 & LC129315 \\
\hline $\begin{array}{l}\text { A. teheranicus Boiss. } \\
\text { \& Hohen. }\end{array}$ & $\begin{array}{l}\text { Babakhanlou \& Amin, } \\
\text { 15069(TARI) }\end{array}$ & *AB727523 & LC129371 & LC129349 & LC129314 \\
\hline $\begin{array}{l}\text { A. ahangarensis Zarre } \\
\text { \& Podl. }\end{array}$ & $\begin{array}{l}\text { Abbasi \& Amirabadi, } \\
\text { 4416(TARI) }\end{array}$ & LC129282 & LC129359 & LC129326 & LC129304 \\
\hline
\end{tabular}

$\operatorname{trnY}$ (Demesure et al., 1995), respectively. The total volume of amplification reaction was $25 \mu \mathrm{l}$, made up of $18 \mu \mathrm{l}$ deionized water, $2.5 \mu \mathrm{l}$ of $10 \times$ PCR buffer, $2.5 \mu \mathrm{l}$ of $2.5 \mathrm{mM}$ dNTPs, $0.5 \mu \mathrm{l}$ of each primer ( 5 pmol $\mu \mathrm{l}-1$ ), $0.25 \mu \mathrm{l}(5$ units per $\mu \mathrm{l}$ ) of TaqDNA polymerase and $0.75 \mu \mathrm{l}$ of template DNA. The PCR profile for ITS consisted of $2.5 \mathrm{~min}$ at $95^{\circ} \mathrm{C}$ for pre-denaturation followed by 27 cycles of $1 \mathrm{~min}$ at $95^{\circ} \mathrm{C}$ for denaturation, $45 \mathrm{sec}$ at $53.7^{\circ} \mathrm{C}$ for primer annealing and $50 \mathrm{sec}$ at $72^{\circ} \mathrm{C}$ for primer extension, and a final primer extension of $7 \mathrm{~min}$ at $72^{\circ} \mathrm{C}$.PCR procedure for amplification of three cpDNA regions was as follows: $3 \mathrm{~min}$ at $94^{\circ} \mathrm{C}, 35$ cycles of $1 \mathrm{~min}$ at $94^{\circ} \mathrm{C}$, $1 \mathrm{~min}$ at $51-64^{\circ} \mathrm{C}, 1.5 \mathrm{~min}$ at $72^{\circ} \mathrm{C}$, and terminal elongation of $7 \mathrm{~min}$ at $72^{\circ} \mathrm{C}$.PCR products were directly used for sequencing reactions. Sequencing of the nrDNA ITS and cpDNA fragments were performed using an ABI 3130Genetic DNA Analyzer (Applied Biosystems, USA).

\section{Sequence alignment}

Sequences of nuclear and plastid DNA were edited by BioEdit package version7 (Hall 1999). The sequence alignment was carried out using ClustalX (Larkin et al., 2007) and adjusted manually. Indel positions were treated as missing data. 
Phylogenetic analyses

Maximum parsimony

Sequenced nuclear and plastid fragments were analyzed separately and in combination, using maximum parsimony method (MP) as implemented in the PAUP* version 4.0b10 (Swofford, 2002). Multiple tree searches were conducted using heuristic search options that included random addition sequences (100 replicates), holding five trees per replicate, and tree bisectionreconnection (TBR) branch swapping with retention of multiple parsimonious trees (Maxtrees = 25000). Bootstrap (BP) support values (Felsenstein, 1985) were calculated using a full heuristic search with 1000 replicates, each with a simple addition sequence and TBR branch swapping. Uninformative characters were excluded from analyses. Parsimony trees were not shown here.

\section{Bayesian analyses}

All datasets separately and in combination, were analyzed using Bayesian inference (BI) as implemented in MrBayes version 3.1.2 (Ronquist and Huelsenbeck, 2003). The incongruent length difference (ILD) test was performed to evaluate the combinability of the all DNA regions studied (Farris et al., 1995). Appropriate evolutionary models for analyzing sequences were selected using the MrModeltest2 (Nylander, 2004) based on the Akaike information criterion (AIC) (Posada and Buckley 2004). K80+I+G, GTR $+\mathrm{I}+\mathrm{G}, \mathrm{GTR}+\mathrm{I}$, and $\mathrm{F} 81+\mathrm{G}$ were chosen as the models that best fit the datasets of nrDNA ITS, trnH-psbA, matK and trnT-trnY respectively. In combined dataset, various sequences were included as separate partitions. BI analyses were run for two million generations, using Markov chain Monte Carlo search. MrBayes performed two simultaneous analyses starting from different random trees $(\mathrm{N}$ runs $=2$ ) each with four Markov chains and trees sampled at every 100 generations. In all analyses average standard deviation of split frequencies had dropped significantly below 0.01 after completion of the generations. Once reaching the stationary phase, trees were collected and after burning in one fourth of them, used to build a $50 \%$ majority rule consensus tree accompanied with posterior probability (PP) values. Trees were showed using TreeGraph2 (Stöver and Müller, 2010).

\section{Results and Discussion \\ nrDNA ITS dataset analyses}

The average length of aligned nrDNA ITS fragment was 596. Three nucleotide sites, of which 60 sites were parsimony informative. The Bayesian tree with posterior probabilities (PP) and bootstrap values is similar to that of MP analysis (Fig. 1). Based on these analyses, four species belonging to the sections Ornithopodium and Onobrychoidei were located at the base of tree as a sister group to a large assemblage of five subclades. Astragalus juladakensis was placed at the base of this group. Members of sections Dissitiflori and Erioceras plus Cytisodes were well intermixed and formed several subclades within a large monophyletic group (Fig. 1). Although relationships among these subclades were not resolved, each one is supported with moderately to highly bootstrap or PP values.

\section{cpDNA and combined datasets analyses}

Parsimony trees obtained from three single cpDNA and the combined cpDNA plus ITS datasets, were topologically identical to those of Bayesian analyses. The length and composition of DNA sequences as well as the tree statistics from the single and combined analyses have been summarized in Table 2. In trnH-psbA tree, A. tehranicus Boiss. \& Hohen. and A. goktschaicus Grossh. belonging to the sect. Onobrychoidei were united in a highly supported subclade $(\mathrm{PP}=1)$ and placed at base of the tree as a sister to the remaining species (Fig. 2). Again, the members of 

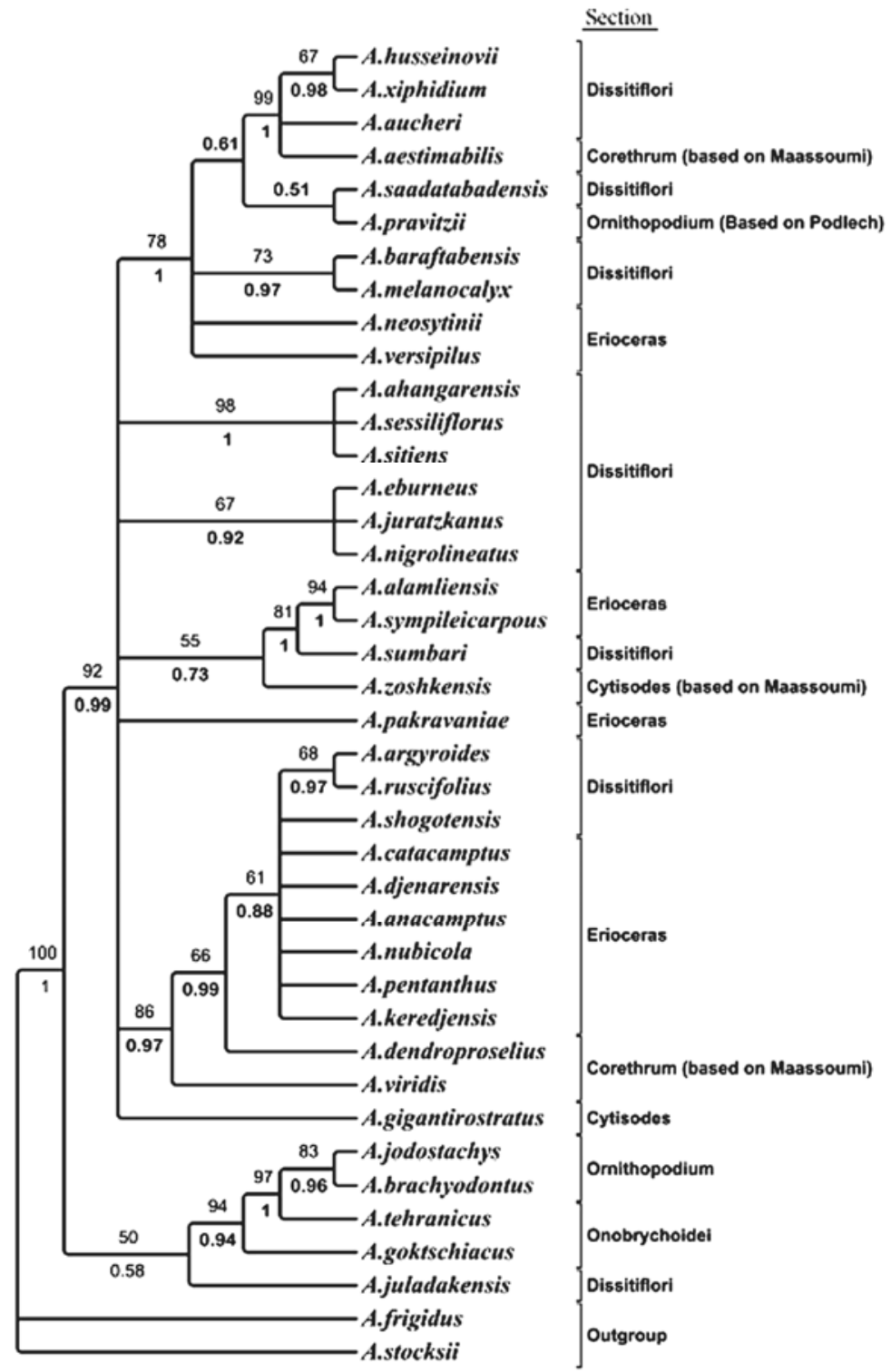

Fig.1. Fifty percent majority rule consensus tree resulting from Bayesian analysis of the nrDNA ITS dataset. Numbers above and below branches are bootstrap values and posterior probabilities, respectively.

sections Dissitiflori and Erioceras plus some controversial species (i.e. A. zoshkensis, A. aestimabilis Podl., A. dendroproselius Rech. f. and A. viridis Bunge) were intermixed within a large polytomic assemblage (Fig. 2). In the matK tree, species sampled from two sections Onobrychoidei and Ornithopodium revealed a highly supported group $(\mathrm{BS}=80 \%, \mathrm{PP}=0.95)$ and placed as a sister to the members of other sections. The remaining species, in this tree as well as two other cpDNA trees, placed together within a polytomic large clade (Fig. 3). trnT-trnY region was not amplified in some of in-groups due to difficulties with the PCR. However, the topology of the tree obtained from this sequence was similar to the other trees in general (tree not shown here). 
Table 2. Dataset and tree statistics from separate and combined analyses of the nuclear and three chloroplast regions.

\begin{tabular}{lccccc}
\hline Data sets & ITS & trnT/trnY & trnH/psbA & matK & combined \\
\hline Nucleotide sites (average) & 596.3 & 629 & 397.7 & 931 & 2554 \\
Variable sites & 120 & 76 & 82 & 61 & 337 \\
Informative characters & 60 & 58 & 44 & 18 & 178 \\
Number of MPTs & 10 & 39 & 6494 & 68 & 398 \\
Length of MPTs & 86 & 74 & 80 & 29 & 335 \\
CI of MPTs & 0.756 & 0.824 & 0.637 & 0.828 & 0.670 \\
RI of MPTs & 0.882 & 0.911 & 0.839 & 0.891 & 0.719 \\
\hline
\end{tabular}

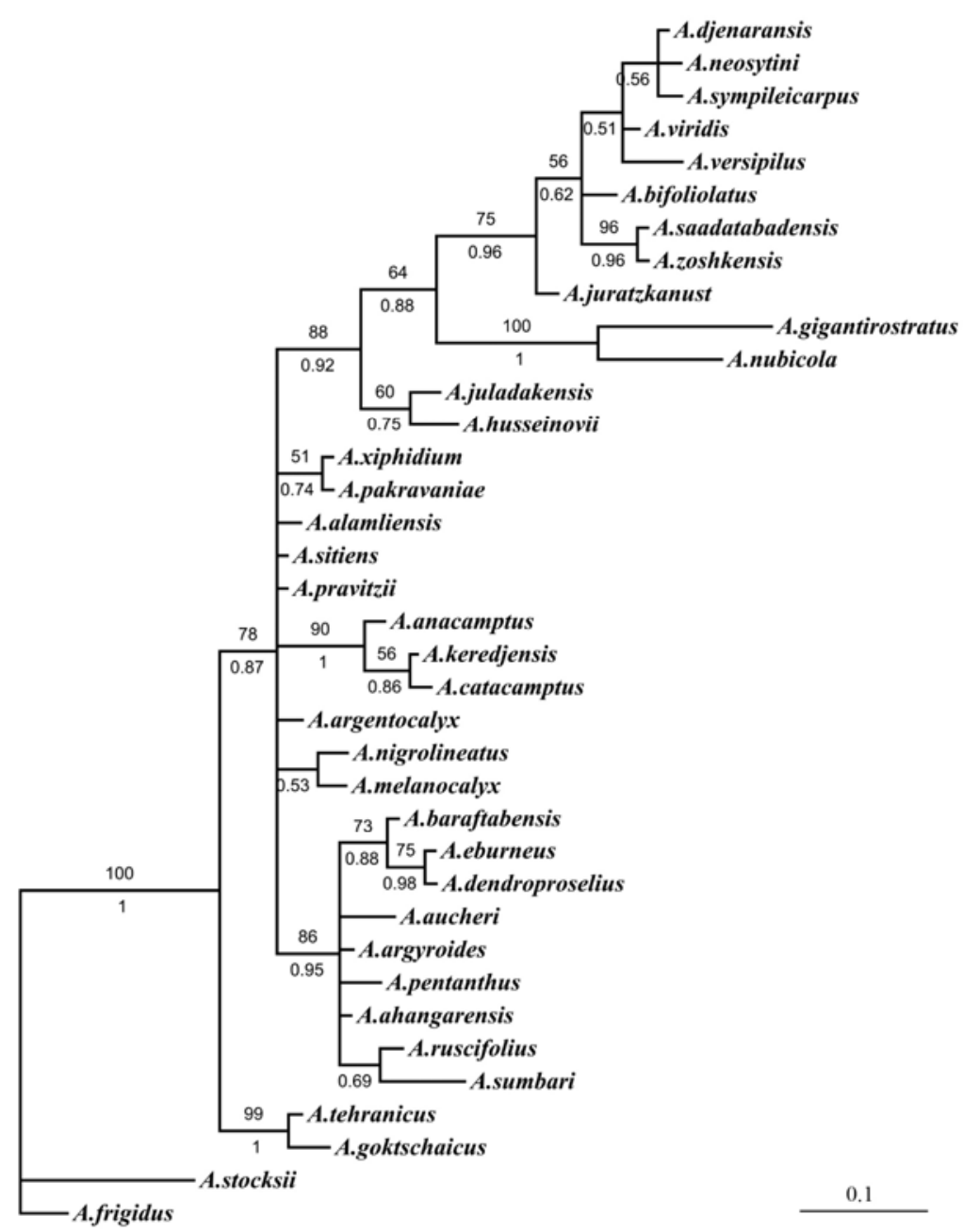

Fig. 2. Fifty percent majority rule consensus tree resulting from Bayesian analysis of the $t r n \mathrm{H} / \mathrm{psbA}$ dataset. Numbers above and below branches are bootstrap values and posterior probabilities, respectively. 
ILD test suggested that the four datasets were slightly incongruent $(P=0.01)$. Following the suggestions of several authors that the ILD test may be unreliable (Seelanan et al., 1997; Wiens, 1998; Yoder et al., 2001), we decided to combine these datasets. The DNA fragments which had not been sequenced for some species in this study were treated as missing data in the combined dataset. The topology of the resulted tree (Fig. 4) was roughly the same as those of single dataset trees, with the exception that resolution, bootstrap and PP values were higher. The combined tree

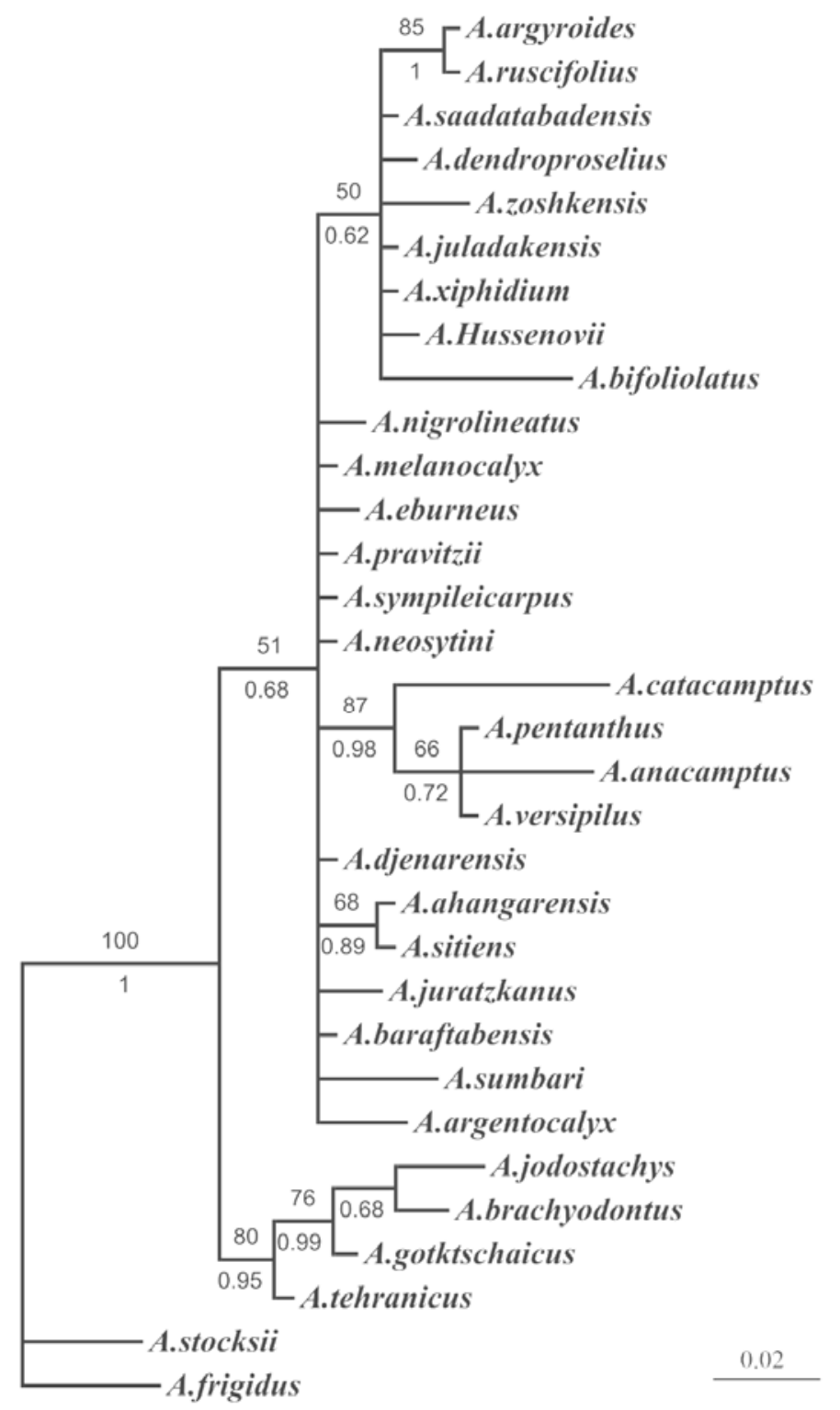

Fig. 3. Fifty percent majority rule consensus tree resulting from Bayesian analysis of the cpDNA matK dataset. Numbers above and below branches are bootstrap values and posterior probabilities, respectively. 
was composed of two obvious clades among in-groups studied. At base of the tree, four species belonging to the sections Onobrychoidei and Ornithopodium were separated from other in groups and formed a highly supported clade as a sister group to the remaining species (Fig. 4). The next main clade was composed of two clades, each of successive subclades including the members of sections Dissitiflori and Erioceras and their closely related taxa. The relationships of these subclades were well resolved (Fig. 4).

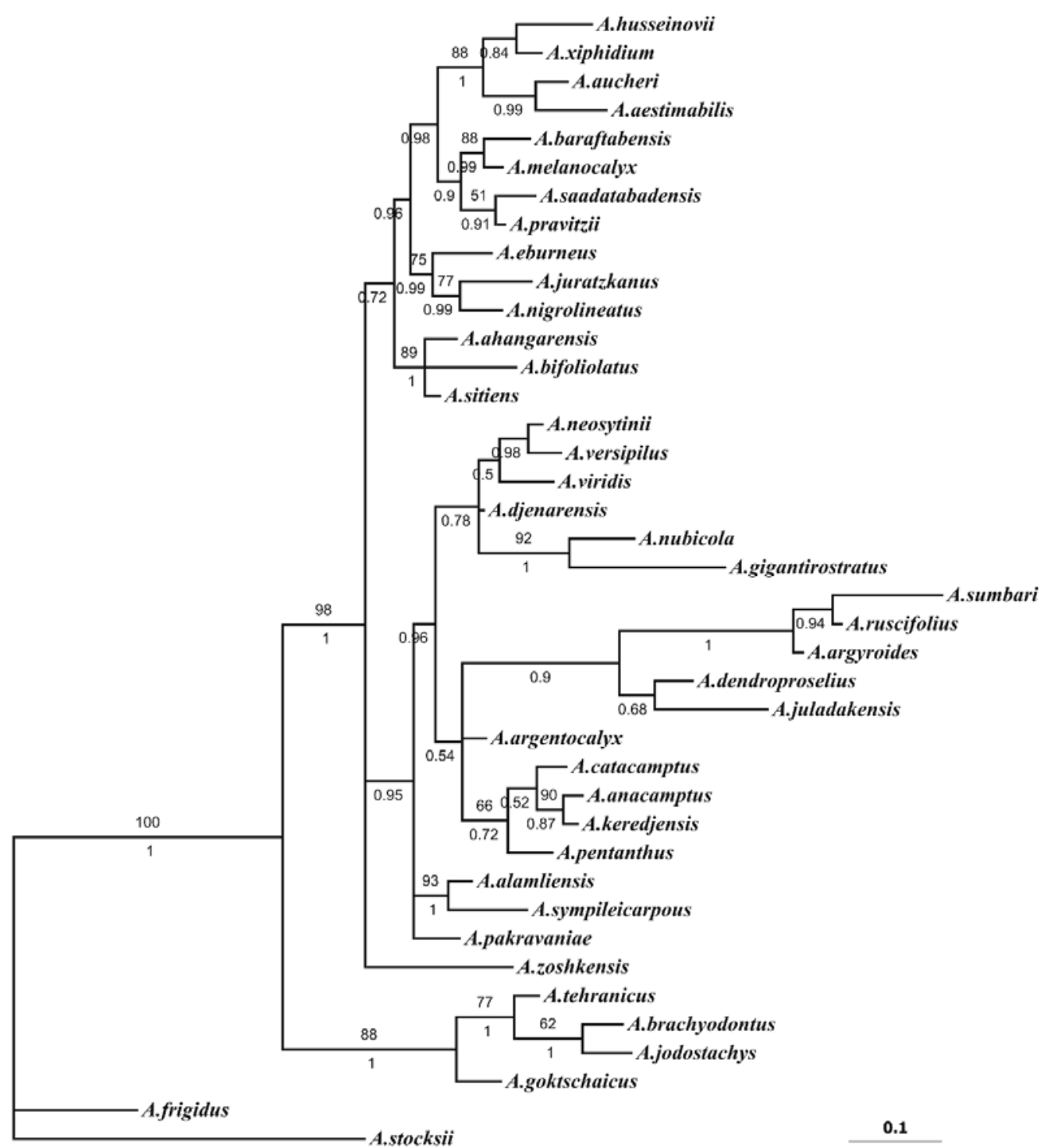

Fig. 4. Fifty percent majority rule consensus tree resulting from Bayesian analysis of the nrDNA and cpDNA combined dataset. Numbers above and below branches are bootstrap values and posterior probabilities, respectively. 
Among different datasets analyzed here, relationships of species were well resolved on the ITS and combined trees. Astragalus sect. Dissitiflori is one of the largest sections of the genus including more than 40 species in the Iranian Plateau (Podlech et al., 2010). Among bifurcate hairy Astragalus, the members of Dissitiflori are distinguished by some features including stem with long internodes, linear pod and asymmetrical and gibbous calyx at the base (Ghahremaninejad, 2004; Sheikh Akbari et al., 2012a). It seems that this section belongs to a group of medifixed hairy Astragalus including A. sect. Cystodes, A. sect. Erioceras, A. sect. Cystium Bunge, A. sect. Cremoceras Bunge and A. sect. Trachycercis Bunge (Ranjbar 2004). This idea is also supported partially with molecular evidences (Kazempour Osaloo et al., 2005; Sheikh Akbari et al., 2012b). Molecular phylogenetic analyses of the present study showed that the members of sections Erioceras and Cytisodes in Iran, were intermixed with those of section Dissitiflori and located within a large assemblage (Fig. 4).

A. juladakensis, which was recently introduced as a new species belonging to the section Dissitiflori (Maassoumi, 2007), revealed some affinity to the members of Onobrychoidei based on ITS sequences and nested at the base of ITS tree, as a sister to the remaining species (Fig. 1). Based on our previous phylogenetic study on the sect. Dissitiflori (based on ITS), this species revealed a separated position among other members of the section and its affinity to the sect. Dissitiflori remained questionable (Sheikh Akbari Mehr et al., 2012b). Despite these results, A. juladakensis, was placed beside the other members of sect. Dissitiflori on the basis of our cpDNA and combined datasets analyses (Fig. 4). On the other hand, this species along with A. husseiovii Rezazade was united within a moderately supported subclade within sect. Dissitiflori, based upon morphological features (Sheikh Akbari et al., 2012a); hence, the positioning of this species within the section Dissitiflori is verified.

A. pravitzii Podl. and A. saadatabadensis Podl. formed a sister subclade within section Dissitiflori, on the basis of ITS and combined trees. After introducing A. pravitzii as a new species from sect. Dissitiflori (Podlech, 2001), Podlech and Sytin (2010) moved it to the sect. Ornithopodium. In accordance with previous morphological data analysis (Sheikh Akbari Mehr et al., 2012a), our present molecular data revealed that this taxon is a member of sect. Dissitiflori (Figs 1, 4).

According to Gontscharov et al. (1946) and Maassoumi (2005), A. sect. Corethrum is closely related to the sect. Dissitiflori but differs with that in having asymmetrical long hairs on calyx and pod shape. Three species (A. aestimabilis, A. dendroproselius and $A$. viridis) belonging to the sect. Dissitiflori were separated from the section and introduced as the members of newly recorded section Corethrum for Iran, based on having ovate-elliptic pods and asymmetrical standing indumentum on calyx (Maassoumi, 2005). However, in accordance with Podlech and Zarre (2013), our present molecular dataset analyses revealed that these taxa belong to the sect. Dissitiflori. sect. Erioceras is characterized by a short stem, prostrate habit, asymmetrical long hairs, oblong elliptic pods and rupturing of calyx (Maassoumi, 2005). It seems that sect. Erioceras has been evolved by reducing of stem length in sect. Dissitiflori (Ranjbar and Karamian, 2002). However, our results obtained from single and combined molecular datasets revealed no distinction between two sections. The members of sect. Erioceras have adapted to arid and windy sub-mountainous regions. They are distributed in arid central and north-eastern of Iran. The evolution of prostrate habit and dense and long hairs within section Erioceras is likely an adaptive behaviour due to its environmental conditions.

Section Cytisodes is a small section among bifurcate hairy Astragalus and is distinguished by their short stem internodes, calyx with standing hairs and long beak on the pod (Bunge, 1868). Maassoumi et al. (1999) introduced a new species from eastern part of Elburz Mountains, showing the features of sect. Cytisodes, and named A. gigantirostratus. Occurrence of this species in the 
Hyrcanian province astonished the authors, because known species of the section are all confined to the Turkestanian floristic province of the Irano-Turanian region. Later on, Podlech (1999) introduced A. neyshaburensis Podl. as a new species from sect. Cytisodes in Iran. Maassoumi (2005) moved A. zoshkensis from section Dissitiflori to the Cytisodes based on calyx hairs and pod features. However, in agreement with a recent morphological study (Sheikh Akbari Mehr et al., 2012a), our present molecular results revealed that these species are placed within section Dissitiflori and it is recommended that section Cytisodes is best to be retreated after complementary studies.

In summary, different genomic sequences revealed that the sect. Dissitiflori with the inclusion of the members of section Erioceras as well as members of Cytisodes in Iran, formed a monophyletic group. The present results indicated that taxa which had been transferred from sect. Dissitiflori have to be returned to the section, and from this point of view, sect. Corethrum has no representative in Iran and this result is in accordance with Podlech et al., (2010) and Podlech and Zarre (2013) classifications. Our findings showed that delimitation of sect. Dissitiflori needs to be revised. Indeed, beside the increase of samples, the analysis of type specimen of aforementioned sections seems to be necessary to assess exact taxonomic situation of taxa discussed above.

\section{Acknowledgments}

We are grateful to the directors and curators of the Central Herbarium of Iran (TARI) and Herbarium of Ferdowsi University (FUMH) for the loan of materials and collections.

\section{References}

Barneby, R. 1964. Atlas of North American Astragalus. Memoirs of the New York Botanical Garden 13: $1-1188$.

Boissier, E. 1843. Diagnoses Plantarum Orientalium Novarum, Ser. I, Part. 2. Typographia Ferd Ramboz, Genevae, pp. 1-115.

Bunge, A. 1868. Generis Astragali Species Gerontogeae. Académie Impériale des Sciences, St. Pétersburg, pp. 1-254.

De Candolle, A.P. 1825. Prodromus Systematis Naturalis, Regni Vegetabilis, Vol 2. Astragaleae. Argentorati et Londii, Parisiis, pp. 1-644.

Demesure, B., Sodzi, N. and Petit, R.J. 1995. A set of universal primers for amplification of polymorphic non-coding regions of mitochondrial and chloroplast DNA in plants. Molecular Ecology 4: 129-131.

Doyle, J.J. and Doyle ,J. L. 1987. A rapid DNA isolation procedure for small quantities of fresh leaf tissue. Phytochemical Bulletin 19: 11-15.

Ekici, M., Akan, H. and Aytac, Z. 2011.Taxonomic revision of Astragalus section Onobrychoidei DC. (Fabaceae) in Turkey. Turkish Journal of Botany 35: 1-73.

Farris, J.S., Kallersjo, M., Kluge, A.G. and Bult, C. 1995. Testing significance of incongruence. Cladistics 10: $315-319$

Felsenstein, J. 1985. Confidence limits on phylogenies: an approach using the bootstrap. Evolution 39: 783-791.

Ghahreman, A., Pakravan, M. and Maassoumi, A. A. 1996. Note on the genus Astragalus (sect. Xiphidium) in Iran. Iranian Journal Botany 7(1): 45-50.

Ghahremani-nejad, F. 2003. Astragalus zoshkensis (Fabaceae), a new species from Iran. Annales Botanici Fennici 40: 117-121.

Ghahremani-nejad, F. 2004. The sections of Astragalus L. with bifurcating hairs in Iran. Turkish Journal of Botany 28: 101-117. 
Gontscharov, N.F., Borissova, A.G., Gorschkova, S.G., Popov, M.G. andVassilczenko, I.T. 1946. Astragalus L. In: Komarov, V.L. and Shishkin,B.K. (Eds), Flora USSR. Vol. 12. Editio Academiae Scientiarum, Leningrad, Russia, pp. 1-681.

Hall, T.A. 1999. BioEdit: a user-friendly biological sequence alignment editor and analysis program for Windows 95/98/NT. Nucleic Acids Symposium Series 41: 95-98.

Kazempour Osaloo, S., Maassoumi, A.A. and Murakami, N. 2003. Molecular systematics of the genus Astragalus L. (Fabaceae): phylogenetic analyses of nuclear ribosomal DNA internal transcribed spacers and chloroplast gene $n d h F$ sequences. Plant Systematics and Evolution 242: 1-32.

Kazempour Osaloo, S., Maassoumi, A.A. and Murakami, N. 2005. Molecular systematics of the Old World Astragalus (Fabaceae) as inferred from nrDNA ITS sequence data. Brittonia 57: 367-381.

Larkin, M.A., Blackshields, G., Brown, N.P., Chenna, R., McGettigan, P.A., McWilliam, H., Valentin, F., Wallace ,I.M., Wilm, A., Lopez, R., Thompson, J.D., Gibson, T.J. and Higgins, D.G.2007. Clustal Wand Clustal X version 2.0. Bioinformatics 23:2947-2948.

Lewis, G.P., Schrire, B.D., Mackinder, B.A. and Lock, M. 2005. Legumes of the world. Kew Publishing, London, UK, pp. 577.

Lock, J.M. and Simpson, K. 1991. Legumes of West Asia: A Check-List. Kew Publishing.

Maassoumi, A. A., Ghahreman, A., Ghahremani-nejad, F. and Matin, F. 1999.Astragalus gigantirostratus (Fabaceae), a remarkable new species from N Iran and supplementary notes on A. sect. Cytisodes Bunge. Willdenowia 29: 221-225.

Maassoumi, A.A. 2000. The genus Astragalus in Iran, Perennials. Research Institute of Forests and Rangeland Publications, Tehran, Iran, pp. 441.

Maassoumi, A.A. 2005. The Genus Astragalus in Iran. Research Institute of Forests and Rangeland Publications, Tehran, Iran, pp. 786.

Maassoumi, A.A.2007. Two new species of the genus Astragalus L. (Fabaceae) from Iran. Iranian Journal of Botany 13(2): 78-81.

Nylander, J.A.A. 2004.MrModeltest, ver. 2. Program distributed by the author. Uppsala University Press, Uppsala, Sweden.

Podlech, D. 1986. Taxonomic and phytogeographical problems in Astragalus of the Old World and southwest Asia. Proceedings of the Royal Society of Edinburgh 89: 37-43.

Podlech, D. 1999. New Astragali and Oxytropis from North Africa and Asia, including some new combinations and remarks on some species. Sendtnera 6: 135-174.

Podlech, D. 2001. Contributions to the knowledge of the genus Astragalus L. (Leguminosae). Sendtnera 7: 163-201.

Podlech, D. 2004. New species of Astragalus L. (Leguminosae), mainly from Iran. Annalen des Naturhistorischen Museums in Wien 105: 565-596.

Podlech, D. and Sytin, A. 2010. Papilionaceae VI: Astragalus section Ornithopodium. In: Rechinger, K.H. (Ed.), Flora Iranica. Vol. 178. Akademische Druck-u Verlagsanstalt, Wien, Austria, pp. 173-184.

Podlech, D., Zarre, SH., Maassoumi, A.A., Ekici, M. and Sytin, A. 2010. Papilionaceae VI: Astragaleae, Astragalus L. IV. In: Rechinger, K.H. (Ed.). Flora Iranica. Vol. 178. Akademische druck-u verlagsanstalt, Wien, Austria, pp. 1-430.

Podlech, D. and Zarre, SH. 2013. A taxonomic revision of the genus Astragalus L. (Leguminosae) in the Old World. Naturhistorisches Museum, Wien, Austria, pp. 2439.

Posada, D. and Buckley, T. 2004. Model selection and model averaging in phylogenetics: advantages of Akaike information criterion and Bayesian approaches over likelihood ratio rates. Systematic Biology 53: 793-808.

Ranjbar, M. 2004. Astragalus sect. Dissitiflori (Fabaceae) in Iran. Nordic Journal of Botany 24 (5): 523-531.

Ranjbar, M. and Karamian, R.2002. Taxonomic study of Astragalus sect. Erioceras (Fabaceae) in Iran, additional notes and key to the species. Nordic Journal of Botany 22(6): 713-717.

Ronquist, F. and Huelsenbeck, J.P. 2003. MrBayes 3, Bayesian phylogenetic inference under mixed models. Bioinformatics 19: 1572-1574. 
Sanderson, M.J. and Liston, A. 1995. Molecularphylogenetic systematics of Galegeae, with special reference to Astragalus. In: Crisp, M. and Doyle, J.J.(Eds.). Advances in legume systematics. Vol. 7. Kew Publishing, London, UK, pp. 331-350.

Sanderson, M.J. and Wojciechowski, M.F. 1996. Diversification rates in a temperate legume clade: are there “so many species”, of Astragalus (Fabaceae)? American Journal of Botany 83: 1488-1502.

Sang, T., Crawford, D.J. and Stuessy, T.F. 1997. Chloroplast DNA phylogeny, reticulate evolution, and biogeography of Paeonia (Paeoniaceae). American Journal of Botany 84: 1120-1136.

Seelanan, T., Schnabel, A. and Wendel, J.F. 1997. Congruence and consensus in the cotton tribe (Malvaceae). Systematic Botany 22: 259-290.

Sheikh Akbari Mehr, R., Maassoumi, A. A., Saidi, A., Kazempour Osaloo, S. and Ghorbani Nohooji, M. 2012a.Morphological cladistic analysis of some bifurcate hairy sections of Astragalus (Fabaceae) in Iran. Turkish Journal of Botany 36: 434-442.

Sheikh Akbari Mehr, R., Saidi, A., Kazempour Osaloo, S. and Maassoumi, A. A. 2012b. Phylogeny of Astragalus section Dissitiflori based on nrDNAITS and morphological data in Iran. Iranian Journal of Botany 18: 1-9.

Stöver, B.C. and Müller, K.F. 2010. TreeGraph 2 Combining and visualizing evidence from different phylogenetic analyses. BMC Bioinformatics 11: 7-15.

Swofford, D. L. 2002. PAUP*: Phylogenetic Analysis Using Parsimony (and other methods). Version. 4.0b10. Sinauer Associates Inc., Sunderland, Massachusetts, USA.

Tate, J.A. and Simpson, B.B. 2003. Paraphyly of Tarasa (Malvaceae) and diverse origins of the polyploid species.Systematic Botany 28: 723-737.

Vural, C., Ekici, M., Akan, H. and Aytac, Z. 2008.Seed morphology and its systematic implications for genus Astragalus L. sections Onobrychoidei DC., Uliginosi Gray and Ornithopodium Bunge (Fabaceae). Plant Systematics and Evolution 274: 255-263.

White, T.J., Bruns, T., Lee, S. and Taylor, J. 1990. Amplification and direct sequencing of fungal ribosomal RNA genes for phylogenetics. In: Innis, M., Gelfand, D., Sninsky, J. and White, T. (Eds). PCR protocols: A guide to methods and applications. Academic Press, San Diego, California, USA, pp. 315322.

Wiens, J.J. 1998.Combining data sets with different phylogenetic histories. Systematic Biology 47: 568-581.

Wojciechowski, M.F., Lavin, M. and Sanderson, M.J. 2004. A phylogeny of Legums (Leguminosae) based on analysis of the plastid matK gene resolves many well-supported subclades within the family. American Journal of Botany 91: 1846-1862.

Yoder, A.D., Irwin, J.A. and Payseur, B.A. 2001. Failure of the ILD to determine data combinability for slow loris phylogeny. Systematic Biology 50(3): 408-424. 